\title{
EVALUASI KAPASITAS PRODUKSI DAN EFISIENSI BIAYA TERHADAP KELANCARAN PROSES PRODUKSI PADA PT. CAHAYA INDAH MADYA PRATAMA
}

\author{
*( Hery Suprapto \\ Prodi Manajemen, Fakultas Ekonomi, Universitas Islam Lamongan \\ $\mathrm{Jl}$. Veteran No.53A Lamongan \\ Telp. (0322 ) 324706, Faks. ( 0322 ) 324706 \\ Email :jpim.unisla@gmail.com
}

\begin{abstract}
ABSTRAK
Didalam suatu perusahaan permasalahan biaya yang paling utama. Hal ini di perlukan untuk menetapkan serta mengendalikan beberapa jumlah biaya yang akan di gunakan untuk produksi, guna meningkatkan efisiensi khususnya efisiensi biaya produksi yang digunakan untuk biaya operasional perusahaan.Suatu kapasitas organisasi merupakan konsep dinamik yang dapat diubah dan dikelola. Masalah yang hendak dicari jawabanya dalam penelitian ini adalah 1) Apakah kapasitas produksi efisiensi biaya berpengaruh secara parsial terhadap kelancaran produksi 2) Apakah kapasitas produksi dan efisiensi biaya berpengaruh secara simultan terhadap efisiensi biaya 3) Manakah diantara produksi efisiensi biaya yang berpengaruh paling dominan terhadap kelancaran produksi. Sejalan dengan masalah tersebut maka penelitian ini dilakasanakan dengan menggunakan metode analisis regresi linier berganda, koefisien korelasi, uji dertiminasi, uji $t$, uji $F$. Dari hasil metode analisa data diperoleh hasil persamaan regresi linier berganda $Y=-1089.911+$ $0,579 X_{1}+0,453 X_{2}$. Untuk Koefisien kolerasi parsial, $X_{1}$ sebesar 0,579 dan $X_{2}$ sebesar 0,453. Koefisien kolerasi berganda sebesar 0,997. Uji Determinasi diperoleh hasil sebsar 0,994. Untuk Uji $t$, diperoleh hasil kapasitas produksi $\left(X_{1}\right) t_{\text {hitung }} 11.147$ $>t_{\text {tabel }} 4$ 403. sehingga Ho ditolak dan Ha diterima, efisiensi biaya $\left(X_{2}\right) t_{\text {hitung }} 5.007>$ $t_{\text {tabel }} 4,303$, sehingga Ho ditolak dan Ha diterima. Sedangkan Uji $F f_{\text {hitung }} 175.569>F$ tabel 19,00, maka Ho ditolak dan Ha diterima.
\end{abstract}

Kata Kunci : Evaluasi kapsitas produksi, Efisiensi biaya dan kelancaran proses produksi

\section{PENDAHULUAN}

Didalam suatu perusahaan permasalahan biaya yang paling utama. Hal ini di perlukan untuk menetapkan serta mengendalikan beberapa jumlah biaya yang akan di gunakan untuk produksi, guna meningkatkan efisiensi khususnya efisiensi biaya produksi yang digunakan untuk biaya operasional perusahaan. Dengan demikian apabila hal itu dapat dilakukan dengan sebenarnya, maka tidak akan terjadi penyimpangan dalam pengendalian biayanya. 
Rumusan masalah pada penelitian ini adalah (1). Apakah kapasitas produksi efisiensi biaya berpengaruh secara parsial terhadap kelancaran produksi pada PT. CAHAYA INDAH MADYA PRATAMA? (2). Apakah kapasitas produksi dan efisiensi biaya berpengaruh secara simultan terhadap efisiensi biaya pada PT. CAHAYA INDAH MADYA PRATAMA? (3). Manakah diantara produksi efisiensi biaya yang berpengaruh paling dominan terhadap kelancaran produksi pada PT. CAHAYA INDAH MADYA PRATAMA? Kapasitas produksi dapat didefinisikan sebagai volume atau jumlah produk yang dapat di hasilkan oleh suatu fasilitas produksi atau perusahaan dalam periode waktu tertentu dengan mengunakan sumber daya yang tersedia saat itu. T. Hani handoko (2011:6) biaya dalam arti luas adalah pengorbanan sumber ekonomi, yang di ukur dalam satuan uang, yang telah terjadi atau yang kemungkinan akan terjadi untuk tujuan tertentu. Tetapi beban dapat didefinisikan sebagai aliran keluar terukur dari barang atau jasa, yang kemudian ditandingkan dengan pendapatan untuk menentukan laba.Mulyadi (2014;8). proses produksi dapat dibedakan baik atas dasar karateristik aliran prosesnya maupun tipe pesanan pelanggan dimensi klafikasi proses produksi pertama adalah aliran produk atau urutan-urutan produk $\mathrm{T}$. Handoko.(2011;122)

Adapun tujuaan penelitian ini adalah (1). untuk mengetahui secara parsial pengaruh kapasitas produksi, standar waktu dan efisiensi biaya terhadap kelancaran produksi pada PT. CAHAYA INDAH MADYA PRATAMA (2). untuk mengetahui secara simultan kapasitas produksi, standar waktu dan efisiensi biaya berpengaruh secara parsial terhadap kelancaran produksi pada PT. CAHAYA INDAH MADYA PRATAMA (3). untuk mengetahui diantara kapasitas produksi, standar waktu dan efisiensi biaya yang paling dominan berpengaruh terhadap kelancaran produksi pada PT. CAHAYA INDAH MADYA PRATAMA

\section{LANDASAN TEORI}

Kapasitas adalah suatu tingkat keluaran, suatu kuantitas keluaran dalam periode tertentu, dan merupakan kuantitas tertinggi yang mungkin selama periode waktu itu. Untuk berbagai keperluan, kapasitas dapat disesuaikan dengan tingkat penjualan yang sedang berfluktuasi yang dicerminkan dalam jadwal produksi induk ( master production schedul ). Hubungan antara kapasitas dan jadwal-jadwal induk adalah sangat penting. Karena jadwal produksi mencerminkan apa yang akan diproduksi suatu perusahaan (tidak perlu apa yang akan dijual), kemampuan untuk memenuhi rencana ini tergantung pada kapasitas yang tersedia sekarang atau dalam jangka pendek di waktu mendatang, atau tergantung pada kemampuannya untuk memperluas kapasitas ini dalam jangka waktu lebih panjang. Jadwal produksi yang realistik menjadi 
keberhasilan operasi suatu perusahaan yang mengakibatkan seluruh jenis sumberdaya terikat untuk memuaskan kebutuhan kuantitasnya dan komitmen hari pengiriman. Dalam hal ini, kapasitas juga berarti jumlah masukan sumberdaya-sumberdaya yang tersedia relatif untuk kebutuhan keluaran pada waktu tertentu, Handoko ( 1999 ).

Biaya Produksi dan efisiensi merupakan salah satu Faktor penting yang harus diperhatikan dari beberapa faktor yang berpengaruh terhadap perusahaan dalam kegiatan menghasilkan produk-produknya. Mengapa demikian ? Perusahaan tentu dalam proses produksinya tentunya menginginkan keuntungan yang besar dengan modal yang minimal dalam setiap usaha produksinya. Oleh karena itu, diperlukannya suatu pemahaman tentang teori-teori biaya dan efisiensi biaya produksi agar suatu perusahaan atau suatu usaha dapat memperhitungkan biaya-biaya yang akan dikeluarkan untuk menghasilkan suatu output barang. Nah pada kesempatan kali ini kita akan membahas artikel terkait dengan Teori Biaya dan Efisiensi Biaya Pada Suatu Kegiatan Produksi. Menurut Hariyati (2007). Biaya produksi dimaksud sebagai kompensasi yang diterima oleh para pemilik faktor - faktor produksi, naman didalam analisis ekonomi, ia diklasifikasikan dalam beberapa golongan sesuai dengan tujuan yang spesifik dari analisis yang dikerjakan. Dalam jangka panjang yaitu suatu periode yang dimana seluruh faktor - faktor produksi dapat berubah - ubah besar dan jumlahnya, artinya tidak ada lagi faktor - faktor produksi yang bersifat tetap.

Kelancaran merupakan hal yang diinginkan oleh setiap orang dalam menjalankan kegiatan apapun. Karena dengan kelancaran maka tujuan yang diinginkan atau direncanakan pun bisa tercapai tanpa gangguan apa pun. Penulis hanya mampu menyebutkan pengertian kelancaran menurut satu ahli saja yaitu menurut Poerwadarminta. Menurutnya, “ Kelancaran adalah keadaan lancarnya sesuatu".

\section{METODE PENELITIAN}

Pendekatan penelitian yang digunakan dalam penelitian ini adalah menggunakan pendekatan deskriptif kuantitatif. Deskriptif kuantitatif mrupakan penyajian tahap lebih lanjut dari observasi setelah memiliki seperangkat skema klasifikasi kemudian mengukur besar atau distribusi sifat-sifat diantara anggotaangota kelompok tertentu. Dalam hal ini muncul peranan tehnik-tehnik statistik seperti distribusi frekuensi, tendensi sentral, dan dipersi (Bungin, 2008 : 49).

\section{Regresi linier berganda}

Digunakan untuk mengetahui bagaimana pengaruh antara variabel bebas (X1 dan X2) dengan variabel terikat (Y) yang menggunakan rumus Regresi Linier Berganda. Analisis ini digunakan untuk mengetahui arah hubungan antara variabel bebas dan variabel terikat, apakah masingmasing variabel bebas berhubungan 
positif atau negatif dan memprediksi perubahan variabel terikat akibat pengaruh dari nilai variabel bebas. Rumus persamaan regresi linier berganda adalah :

$\mathrm{Y}=\mathrm{a}+\mathrm{b}_{1} \mathrm{x}_{1}+\mathrm{b}_{2} \mathrm{x}_{2}+\mathrm{e}$

Hasil penghitungan analisis regresi berganda pengaruh variabel bebas yaitu Evaluasi kapasitas produksi dan efisiensi biaya terhadap variabel terikat yaitu kelancaran proses produksi, dapat dilihat pada tabel berikut

\section{Koefisien Korelasi Persial}

Analisis Kolerasi adalah suatu Teknik statistika yang digunakan untuk mengukur keeratan hubungan atau kolerasi antara dua variabel.

Analisis Kolerasi mencoba mengukur keratan hubungan antara dua variabel $\mathrm{X}$ dan $\mathrm{Y}$. Keeratan hubungan antara dua variabel tersebut dinyatakan dalam bentuk koefisien kolerasi yang dilambangkan dengan huruf r. Koefisien kolerasi (r) menunjukkan seberapa dekat titik kombinasi anatra variabel $\mathrm{X}$ dan $\mathrm{Y}$ pada garis lurus sebagai garis dugaannya. Semakin dekat titik kombinasi maka dengan garis dugaannya maka nilai kolerasi semakin kecil. Menurut Suharyadi Purwanto S.H dalam bukunya Statistik (2013:158/159).

\section{Koefisien Korelasi Berganda}

Korelasi Berganda merupakan korelasi yang digunakan untuk menguji hubungan dua atau lebih variabel independen dengan satu variabel dependen secara bersamaan.
Pengambilan keputusan dalam uji korelasi berganda adalah semakin nilai hasil korelasi mendekati 1 maka korelasi semakin kuat, dan sebaliknya jika semakin dekat dengan 0 maka korelasi diartikan semakin lemah dan jika nilai korelasi 0 dapat diartikan bahwa tidak ada korelasi atau tidak ada hubungan antara variabel independen dan variabel dependen tersebut.

\section{Koefisien Determinasi}

Koefisien determinasi $\left(\mathrm{R}^{2}\right)$ pada intinya mengukur seberapa jauh kemampuan model dalam menerangkan variasi variabel dependen. Nilai koefisien determinasi adalah antara nol dan satu.

1. Ujit

Uji $t$ dalam penelitian ini dilakukan untuk mengetahui apakah variabel independen $(\mathrm{X})$ secara parsial berpengaruh signifikan terhadap variabel dependen (Y). Dasar pengambilan keputusan dalam uji $\mathrm{t}$ berdasarkan nilai $\mathrm{t}$ hitung dan $\mathrm{t}$ tabel.

Jika nilai $\mathrm{t}$ hitung > $\mathrm{t}$ tabel sehingga Ho ditolak dan $\mathrm{Ha}$ diterima. maka variabel independen berpengaruh terhadap variabel dependen

Jika nilai $\mathrm{t}$ hitung $<\mathrm{t}$ tabel sehingga Ho diterima dan Ha ditolak, maka variabel independen tidak berpengaruh terhadap variabel dependen

\section{Uji F}

Uji F digunakan untuk mengetahui apakah variabel independen secara simultan (bersama-sama) berpengaruh signifikan terhadap variabel dependen. 
Selain itu uji $\mathrm{F}$ juga digunakan untuk mengetahui model regresi dapat digunakan untuk memprediksi variabel dependen atau tidak.

\section{HASIL PENELITIAN DAN PEMBAHASAN}

Berikut ini adalah Data Proses Produksi Pada PT. CAHAYA INDAH MADYA PRATAMA

Tabel. 1

Produksi Beton Tahun 2010 - 2014

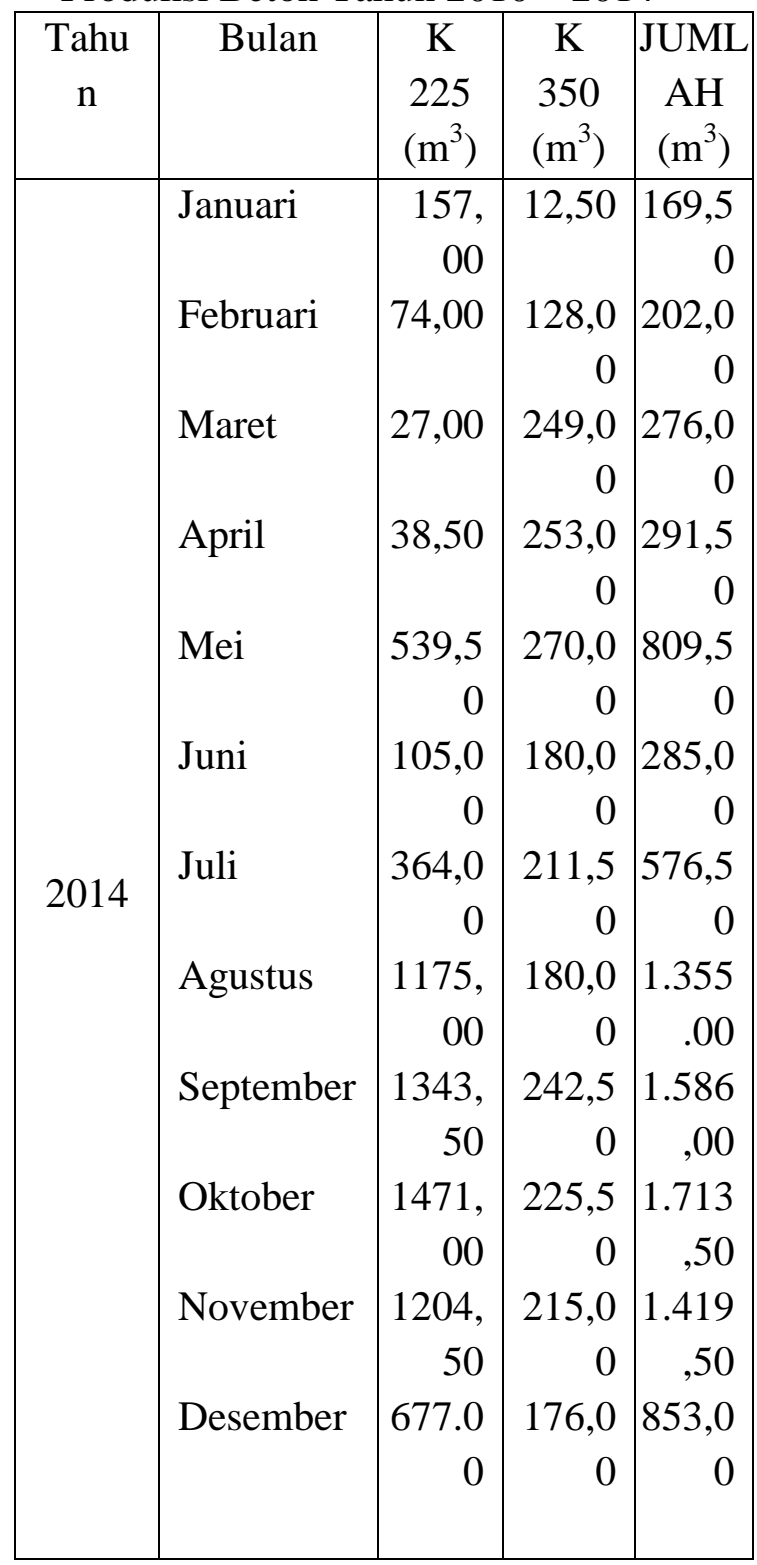

\begin{tabular}{|c|c|c|c|c|}
\hline & Januari & 438 & 310,5 & 749,0 \\
\hline & & 50 & 0 & 0 \\
\hline & Februari & 269,5 & 323,0 & 501,5 \\
\hline & & 0 & 0 & 0 \\
\hline & Maret & 748,5 & 151,0 & 899,0 \\
\hline & & 0 & 0 & 0 \\
\hline & April & 46,00 & 96,50 & 142,5 \\
\hline & & & & 0 \\
\hline & Mei & 19,50 & 42,00 & 61,50 \\
\hline & Juni & 81,50 & 141,5 & 223,0 \\
\hline & & & 0 & 0 \\
\hline 2013 & Juli & 226,0 & 128,0 & 354,0 \\
\hline & & 0 & 0 & 0 \\
\hline & Agustus & 903,0 & 35,00 & 938,0 \\
\hline & & 0 & & 0 \\
\hline & September & 1355 & 188,0 & 1.543 \\
\hline & & 00 & 0 & .00 \\
\hline & Oktober & 1260 & 621,5 & 1.882 \\
\hline & & 50 & 0 & , 00 \\
\hline & November & 1652 & 162,5 & 1.814 \\
\hline & & 00 & 0 &, 50 \\
\hline & Desember & 695,5 & 51,00 & 746,5 \\
\hline & & 0 & & 0 \\
\hline & Januari & 70 & 50,00 & 150,0 \\
\hline & ERhmi & 0050 & 7200 & 165 \\
\hline & Tetriant & (20, & 12,00 & $\begin{array}{r}102,0 \\
0\end{array}$ \\
\hline & Maret & 140,5 & 60,00 & 204,5 \\
\hline & & 0 & & 0 \\
\hline & April & 96,50 & 84,00 & 180,0 \\
\hline 2012 & Mei & 467 & 1230 & 5900 \\
\hline & & & 0 & 0 \\
\hline & Juni & 137 & 142,0 & 278,5 \\
\hline & & & 0 & 0 \\
\hline & Juli & 367 & 231,5 & 598,5 \\
\hline & & & 0 & 0 \\
\hline & Agustus & 511 & 501,0 & 1.012 \\
\hline & & & 0 & ,00 \\
\hline & September & 80,50 & 486,0 & 1.286 \\
\hline
\end{tabular}




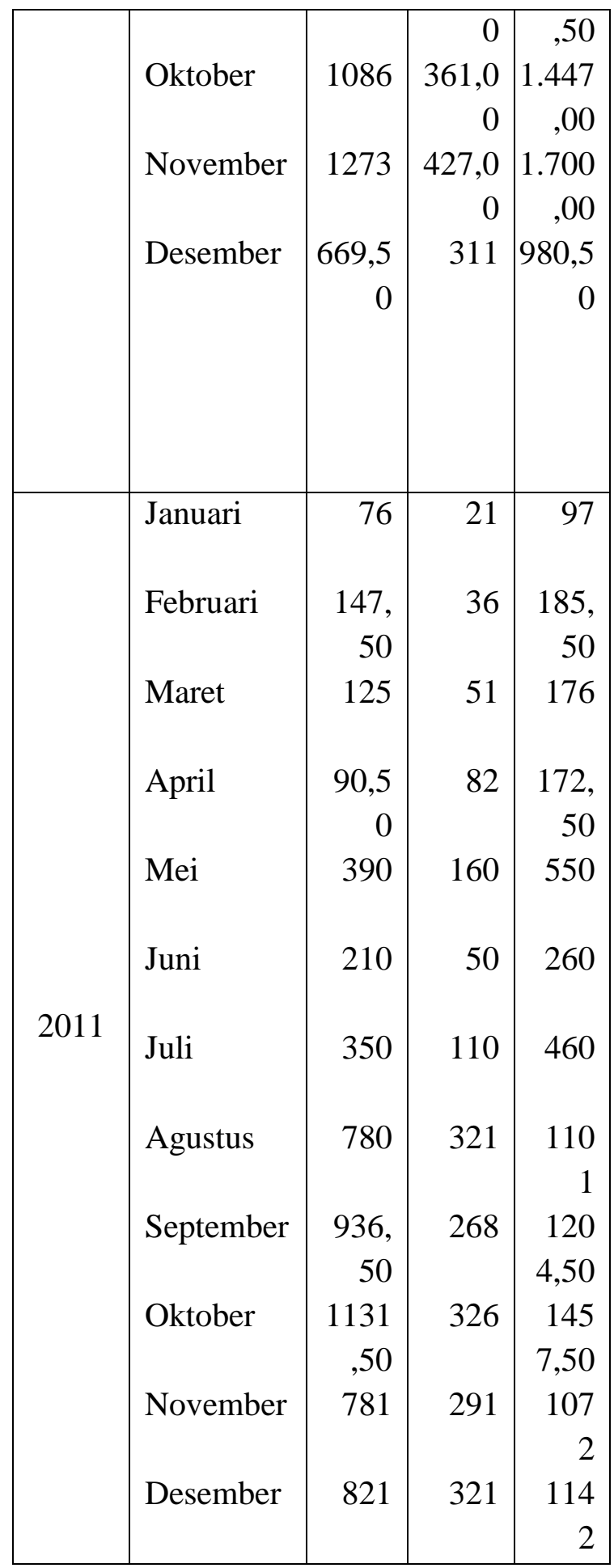

\begin{tabular}{|c|c|c|c|c|}
\hline \multirow{12}{*}{2010} & Januari & 67 & 18 & 85 \\
\hline & Februari & $\begin{array}{r}136 \\
50\end{array}$ & 31 & $\begin{array}{r}167 \\
50\end{array}$ \\
\hline & Maret & 185 & 21 & 206 \\
\hline & April & $\begin{array}{r}100 \\
50\end{array}$ & 56 & $\begin{array}{r}156 \\
50\end{array}$ \\
\hline & Mei & 310 & 271 & 581 \\
\hline & Juni & 200 & 50 & 250 \\
\hline & Juli & $\begin{array}{r}295 \\
50\end{array}$ & 75 & $\begin{array}{r}370 \\
50\end{array}$ \\
\hline & Agustus & $\begin{array}{r}861, \\
50\end{array}$ & 60 & $\begin{array}{r}921, \\
50\end{array}$ \\
\hline & September & 949 & 191 & $\begin{array}{r}114 \\
0\end{array}$ \\
\hline & Oktober & $\begin{array}{r}1261 \\
, 50\end{array}$ & 245 & $\begin{array}{r}150 \\
6,50\end{array}$ \\
\hline & November & $\begin{array}{r}821 \\
50\end{array}$ & 296 & $\begin{array}{r}111 \\
7,50\end{array}$ \\
\hline & Desember & 785 & 301 & 108 \\
\hline
\end{tabular}

perusahaan Beton

Dalam table hasil kapasitas produksi dari tahun ke tahun terus mengalami peningkatan. Pada tahun 2010 hasil kapasitas produksi sebesar 7150, ditahun 2011 mengalami peningkatan kapasitas produksi sebesar 9805, ditahun 2012 mengalami peningkatan kapasitas produksi 10250, ditahun 2013 peningkatan kapasitas produksi 12475, dan ditahunn 2014 hasil kapasitas produksi sebesar 12475. Sehingga bisa disimpulkan dari lima tahun terakhir perusahaan terus mengalami peningkatan kapasitas produksi. 
Table 2.

Efisiensi Biaya Tenaga Kerja, Overhead (Ribuan)

\begin{tabular}{|c|c|}
\hline Tahun & Biaya \\
\hline 2010 & 12785 \\
\hline 2011 & 11805 \\
\hline 2012 & 12250 \\
\hline 2013 & 13540 \\
\hline 2014 & 14755 \\
\hline
\end{tabular}

Sumber : Data Biaya Tenaga

Kerja Perusahaan

Dalam tabel 5.3 hasil efisiensi biaya produksi dari tahun ke tahun terus mengalami peningkatan. Pada tahun 2010 hasil biaya produksi sebesar 12785, ditahun 2011 mengalami penurunan biaya sebesar 11805, ditahun 2012 mengalami peningkatan biaya 12250 , ditahun 2013 peningkatan biaya 13540, dan ditahunn 2014 hasil biaya produksi sebesar 14755. Sehingga bisa disimpulkan ditahun 2010 ke 2011 perusahaan mengalami penurunan biaya produksi, dan ditahun selanjutnya terus mengalami peningkatan.

Table 3.

Hasil produksi PT. Cahaya Indah tahun 2010-2014 (Ribuan)

\begin{tabular}{|c|c|}
\hline Tahun & Produksi \\
\hline 2010 & 8850 \\
\hline 2011 & 9785 \\
\hline 2012 & 10.570 \\
\hline 2013 & 11.752 \\
\hline 2014 & 12.785 \\
\hline
\end{tabular}

Sumber : Data Pruksi Perusahaan

Dalam tabe hasil kelancaran produksi dari tahun ke tahun terus mengalami peningkatan. Pada tahun
2010 hasil kapasitas produksi sebesar 8850, ditahun 2011 mengalami peningkatan kapasitas produksi sebesar 9785, ditahun 2012 mengalami peningkatan kapasitas produksi 10570, ditahun 2013 peningkatan kapasitas produksi 11752, dan ditahunn 2014 hasil kapasitas produksi sebesar 12785. Sehingga bisa disimpulkan dari lima tahun terakhir perusahaan terus mengalami peningkatan kapasitas produksi.

\section{KESMPULAN DAN SARAN}

\section{Kesimpulan}

1. Dalam pengujian secara parsial antara evaluasi kapasitas produksi $\left(\mathrm{X}_{1}\right)$ terhadap kelancaran proses produksi (Y) dan efisiensi biaya $\left(\mathrm{X}_{2}\right)$ terhadap kelancaran proses produksi (Y). diperoleh hasil uji t

a. Evaluasi kapasitas produksi $\left(\mathrm{X}_{1}\right)$ sebesar $t_{\text {hitung }} 11.147>t_{\text {tabel }}$ 4.303menunjukan adanya hubungan yang signifikan antara efisiensi biaya dan kelancaran proses produksi Nilai positif ( 11.147) menunjukan pengaruh positif dimana jika evaluasi kapasitas produksi mengalami kenaikan maka perolehan laba akan mengalami kenaikan

b. Efisiensi biaya $\left(\mathrm{X}_{2}\right)$ sebesar $\mathrm{t}_{\text {hitung }}$ $5.007>t_{\text {tabel }} 4.303$ menunjukan adanya pengaruh yang signifikan antara efisiensi biaya dengan kelancaran proses produksi. Nilai positif 5,007 menunjukan hubungan positif atau searah antara efisiensi biaya dengan 
kelancaran proses produksi, dengan kata lain jika efisiensi biaya mengalami kenaikan maka kelancaran proses produksi akan mengalami kenaikan yang sama.

Dari interpretasi diatas dapat disimpulkan bahwa hipotesis pertama yang diambil adalah benar bahwa evaluasi kapasitas produksi dan efisiensi biayaberpengaruh secara parsial terhadap kelancaran proses produksi.

2. Pengaruh secara simultan atau bersama-sama antara evaluasi kapasitas produksi $\left(\mathrm{X}_{1}\right)$ dan efisiensi biaya $\left(\mathrm{X}_{2}\right)$ terhadap kelancaran proses produksi (Y) dibuktikan dengan uji;

a. Uji regresi linier berganda, diperoleh persamaan;

$\mathrm{Y}=-1089.911+0,579 \mathrm{X}_{1}+$ $0,453 \mathrm{X}_{2}$

Dari persamaan tersebut dapat dijelaskan hubungan simultan, yaitu;

$a=\quad-1089.911 \quad$ merupakan konstanta yang berarti apabila eavaluasi kapasitas produksi dan efisiensi biaya bernilai tetap atau konstan, maka kelancaran proses produksi yang diperolah adalah sebesar -1089.911

$\mathrm{b}_{1}=0,579$ artinya, apabila jika evaluasi kapasitas produksi $\left(\mathrm{X}_{1}\right)$ mengalami kenaikan satu satuan sedangkan efisiensi biaya $\left(\mathrm{X}_{2}\right)$ konstan, maka kelancaran proses produksi (Y) akan mengalami kenaikan sebesar 0,579

$\mathrm{b}_{2}=0,453$ artinya adalah apabila jika evaluasi kapasitas produksi $\left(\mathrm{X}_{1}\right)$ bernilai konstan sedangkan efisiensi biaya $\left(\mathrm{X}_{2}\right)$ mengalami kenaikan satu satuan maka laba (Y) akan mengalami kenaikan sebesar 0,453

b. Uji korelasi berganda yang diperoleh nilai koefisien korelasi sebesar 0,997 dan koefisien determinasi $\left(\mathrm{R}^{2}\right)=$ 0,994. menunjukan pengaruh yang kuat antara variabel bebas dan variabel terikat dengan prosentase nilai $\mathrm{R}^{2}$ sebesar $99,4 \%$ dan $\mathrm{r}$ mendekati 1.

c. Uji $F$, nilai $F$ hitung diperoleh sebesar 175.569 maka $F_{\text {hitung }}$ $175.569>F_{\text {tabel }} 19,00$. Hasil tersebut mununjukan adanya pengaruh yang signifikan antara evaluasi kapasitas produksi dan efisiensi biaya secara simultan terhadap kelancaran proses produksi.

Hasil dari uji regresi linier, korelasi berganda, determinasi dan uji $\mathrm{t}$ dapat disimpulkan bahwa hipotesis yang kedua adalah benar, bahwa evaluasi kapasitas produksi dan efisiensi biaya berpengaruh secara simultan terhadap kelancaran proses produksi

3. Dari keseluruhan interpretasi diatas baik secara parsial maupun simultan dapat disimpulkan bahwa evaluasi kapasitas produksi dan efisiensi biaya berpengaruh terhadap kelancaran proses produksi. Kedua variabel tersebut mempunyai kontribusi yang berbeda terhadap kelancaran 
proses produksi, dibuktikan dari nilau uji yang berbeda. Untuk menentukan kontribuksi mana yang lebih dominan dapat dilihat dari hasil perolehan regresi linier berganda dengan persamaan;

$\mathrm{Y}=-494404.450-164684.142 \mathrm{X}_{1}$

$+0.028 \mathrm{X}_{2}$, menunjukan nilai volume penjualan lebih dominan karena bernilai positif. perputaran modal bernilai negatif sehingga pengaruhnya dikecualikan, maka varibel volume penjualan dapat diartikan lebih dominan dari pada perputaran modal

Dari uji $t$ diperoleh $t_{\text {hitung }}$ perputaran modal 4.811 dan $t_{\text {hitung }}$ volume penjualan sebesar 12.282 yang menunjukan volume penjualan lebih berpengaruh signifikan terhadap perolehan laba dari pada perputaran modal.

Dari hasil tersebut dapat disimpulkan bahwa hipotesis yang ketiga ditolak karena volume penjualan lebih berpengaruh terhadap laba dari pada perputaran modal dengan pembuktian yang telah dipaparkan diatas.

\section{Saran}

1. Perusahaan agar mencacapai proses produksi harusnya melihat beberapa aspek, seperti sdm dan cuaca alam

2. Penelitian ini sebagai bentuk terimaksih kepada Universitas yang telah memberikan sarana menuntut ilmu, terutama dalam bidang manajemen, dan juga penelitian ini akan menambahkan keperpustakaan dibidang ekonomi manajemen dan dapat dijadikan sebagai bahan bacaan yang berisikan suatu studi perbandingan yang bersifat karya ilmiah agar suatu saat berguna sebagai bahan referensi atau acuan yang mengadakan penelitian dalam bidang yang sama dan untuk menambah wawasan dan pengetahuan, khususnya tentang perbankan konvensional.

3. Sebagai bahan bacaan atau refrensi untuk perbandingan materi perkuliahan program manajemen.

\section{DAFTAR PUSTAKA}

Ir. Ibrar Husen , MT, 2010 Manajemem proyek. Yogyakarta ; C.V. Andi Offset

Prof. Dr. Sugiyono, 2011 Metode Penelitian

Kuantitatif

,Kualitatif Dan $R \& D$. Bandung; CV Alvabeta

Hendra Kusuma, 2009.Manajemen Pencanaan Dan Pengendalian Produksi. Jakarta; PT Rajagrafindo persaja

T handoko, 2010. Dasar-dasar Manajemen produksi Dan Opertasi. Gramedia Bandung

Sofyan asauri 2000. Manajemen Produksi Dan Operasi Jakarta: Fakultas Ekonomi Universitas Islam

Sofyan asauri 2004. Manajemen produksi dan Operasi Edisi Revisi ; Fakultas Ekonomi Universitas Islam 